\title{
Developing Selected Aspects of Intercultural Communicative Competence in the EFL Lower Primary Classroom: Learners' Perceptions of Online Culture- Based Lessons
}

\begin{abstract}
The present paper aims to outline a study devoted to the implementation of Intercultural Communicative Competence (ICC) into primary online classroom practice. The selected aspects of Anglophone cultural content were chosen to complement students' own culture issues covered by the core curriculum. The cultural elements were incorporated into the background of EFL materials focusing on teaching vocabulary by means of a range of activities suitable for primary school learners (42 second graders). The conclusions to be presented will provide the researchers' reflections on the implementation of and the students' response to the lessons.

Keywords: Intercultural Communicative Competence, lower primary EFL classroom, culture in ELT, online lessons
\end{abstract}

\section{Introduction}

Recently, there has been a strong tendency towards promoting Intercultural Communicative Competence among EFL learners. This is believed to enhance not only their language learning but also understanding of today's world. Still, developing intercultural competence in the EFL primary classroom can be a fairly challenging task, both on the side of the teacher and the students. Kramsch (1993) notices that language learners are frequently not in a position to interpret many behaviours and norms present in their native environment, not to mention the culture referring to a language that they have just started learning. Hence, in order to be able to con-

\footnotetext{
Izabela Jarosz, Katedra Językoznawstwa Angielskiego i Ogólnego, Instytut Neofilologii, Uniwersytet Marii Curie-Skłodowskiej, PI. Marii Curie-Skłodowskiej 4a, 20-031 Lublin, Phone: 0048815372799 , izabela. jarosz@mail.umcs.pl,http://orcid.org/0000-0002-0543-9595
}

Anna Kiszczak, Katedra Językoznawstwa Angielskiego i Ogólnego, Instytut Neofilologii, Uniwersytet Marii Curie-Skłodowskiej, PI. Marii Curie-Skłodowskiej 4a, 20-031 Lublin, kiszczak.anna@gmail.com, https://orcid.org/0000-0002-9394-3782

Małgorzata Krzemińska-Adamek, Katedra Językoznawstwa Angielskiego iOgólnego, Instytut Neofilologii, Uniwersytet Marii Curie-Skłodowskiej, PI. Marii Curie-Skłodowskiej 4a, 20-031 Lublin, malgorzata. krzeminska-adamek@mail.umcs.pl,https://orcid.org/0000-0003-2461-2397 
vey a foreign culture, the teacher must be sure they understand their own culture with regard to a certain issue. Siek-Piskozub (2014) suggests that with primary school learners at low levels, intercultural competence can focus on their native language, with foreign language teachers occasionally engaging in the process of developing students' ICC. Still, taking into account Brewster's (2002) view that children learn holistically and cross-curricular teaching works best with them, there is no need to separate a foreign language from its culture in order to build some aspects of ICC. In our mind, intercultural competence could be built from the very beginning in an L2, basing on the knowledge about the native culture young learners get in their L1 during subject integrated classes. Therefore, an EFL culture-based course for young learners would be advisable in order to search for some kind of integration with the students' native elements of culture and respond to their needs of holistic learning. In order to discuss the development of some aspects of ICC in the primary classroom through an EFL culture-based lesson design, it is now useful to define the term in more details.

\section{Language and culture interrelations}

As it is outlined by a number of scholars, language and culture are inseparable and one cannot be acquired without the other. Among others, it is Malinowski (1923, p. 306) who indicates that it is necessary to include cultural aspects in linguistic analysis. For the anthropologist, both the context of situation and the context of culture are core for the proper understanding of an utterance, or a text. This is how Malinowski (1923) defines the issue:

[T] he meaning of a single word is to a very high degree dependent on its context [...]. [T] he conception of context must burst the bonds of mere linguistics and be carried over into the analysis of the general conditions under which a language is spoken [...]. [T] he study of any language spoken by a people who live under conditions different from our own and possess a different culture, must be carried out in conjunction with the study of their culture and their environment (p. 306).

In other words, the semantics of a lexical unit cannot be studied independently of context that is understood as culture and general conditions a given speech community lives in.

Wierzbicka (1997, pp. 1-2) particularly emphasizes a close connection between the life of a given society and the lexicon of the language used by this society, taking into account both the outer and inner aspects of life. Strictly speaking, "words can tell us something about the [...] habits of the people". Such a wide existence of language-specific words denoting special kinds of "things", various customs and social institutions cannot be a matter of accident. For instance, as Fillmore (1982, p. 120) explains, the word vegetarian denoting "a person who avoids meat deliberately" exists due to the fact that in our culture, most of the 
community regularly eats meat. Hence, "someone who eats only vegetables" seems "a relevant and interesting category against the background of [meat eating] society". Broadly speaking, as Wierzbicka (1997, p. 2) puts it, "what applies to material culture and to social rituals and institutions applies also to people's values, ideals, and attitudes and to their ways of thinking about the world and our life in it". Wierzbicka (1997) points out that

the meanings of words from different languages don't match [...] [due to the fact] that they reflect and pass on ways of living and ways of thinking characteristic of a given society [...] and that they provide priceless clues to the understanding of culture (p. 4).

In other words, it is impossible to establish fixed boundaries of words' meanings because they mirror human cultural practices and ways of thinking that are changeable and fluid.

For the aforementioned reasons, learning a foreign language without understanding its culture seems to be hardly possible. As Gill and Cankova (2002) notice, it is understanding culture that can guarantee successful communication in foreign language learning. It is extremely important to understand the customs, lifestyles and views as well as history, economy or achievements of the community whose language one is learning. All of them form the background to understand "what, how, and why people communicate in the way they do" (p. 1). The natural part of learning a language is also the curiosity about the people whose culture is foreign to us.

Kramsch (1993) claims that learning another language cannot exclude learning about the culture with which it is associated. As the author puts it, "if language is seen as a social practice, culture becomes the very core of language teaching" (p. 8). Hence, if an FL learner is to be a truly competent foreign language speaker, it seems that language and culture cannot be separated and thus taught independently.

\subsection{The place of culture in foreign language education}

Siek-Piskozub (2014) points out that in language education, developing communicative competence has proved to be not efficient enough for successful communication for a number of reasons. First of all, it has become evident that native-like communicative competence in a foreign language does not guarantee successful communication between members belonging to different cultural backgrounds. The possible reason is in the differences in the mental structure of the speakers and the inability to build and maintain own and foreign identity. Besides, the classroom activities used to develop communicative competence usually refer to "a socio-culturally neutral native speaker" (p. 22).

Along similar lines, Corbett (2003, p. 2) explains that in the communicative approach there was an emphasis on native-like proficiency and the four skills. Com- 
municative competence was the goal of each lesson. In the intercultural approach, learners need "to be 'diplomats', able to view different cultures from a perspective of informed understanding". Therefore, it is not only language development and improvement, but also intercultural understanding and mediation that should be emphasised.

Hence, culture is not attached here as yet another element enhancing successful communication for EFL learners. Kramsch (1993, p. 1) underscores that culture is not a fifth element added to the four skills of communicative competence, but rather it is always present in the background of a language lesson. Kramsch (1993, p. 205) assumes that teaching culture does not mean teaching facts but developing understanding which can be achieved when a learner begins to feel like a foreigner in a communicative situation, always taking into account his/her native culture.

Tomalin and Stempleski (1993) add that the tasks in a foreign language classroom should focus on developing the following: the awareness of learners' own cultural behaviour, the awareness of the cultural behaviour of others, and the ability to explain learners' own cultural standpoint. Apart from teaching "achievement culture", the subject of the lesson should focus on expanding the so-called "behaviour culture" (p. 5), so that it could include culturally-influenced beliefs and perceptions expressed both through language and cultural behaviours that guarantee acceptability in the host community.

Byram (1997, p. 33) distinguishes four key components of Intercultural Communicative Competence: knowledge, attitude, skills of interpretation and comparison, and skills of discovery and interaction. Naturally, these are learned through real-life experience. It goes without saying that familiarizing oneself with another culture and developing real intercultural skills requires becoming an active member of a given culture, or what Byram (1997, p. 1) calls a 'sojourner', not a tourist. Sill, according to Byram (1997, p. 33), it is advisable to promote the components of ICC in the EFL classroom environment, stressing the importance of treating them like "attributes that people bring to the situation rather than abilities which can be produced there in a short time".

Much in a similar vein Kramsch (2001) notices that

the ultimate goal of cultural learning is not to convey information about a culture nor to promote the acquisition of culturally influenced ways of behaving, but rather to help learners see their culture in relation to others so as to promote cross-cultural understanding (p. 229).

In other words, it is not cultural knowledge and memorization of certain behaviour patterns and social norms that guarantees intercultural communicative competence, but rather the ability to notice own and foreign culture in a perspective that guarantees understanding. 
As Byram and Morgan (1994, pp. 55-60) notice, people belonging to different cultures have different perspectives according to which they perceive the surrounding reality. Entering a foreign culture means then contradicting one's own culture. It is, therefore, the role of the teacher to indicate various perspectives by outlining similarities and differences between a native and foreign culture. What is important is the cultural experience not the cultural conscience. Thus, as Sercu (2005) notices, "language teaching has two sides: a language side and a culture side, and that one of the greatest pedagogical challenges consists in integrating these two sides so that students get a sense of their interconnectedness" ( $\mathrm{p}$. vii). To put it in other words, it is the role of the teacher to show students both sides and teach them how to relate the two perspectives in order to become intercultural speakers.

Byram (1997) underscores that a teacher successful in promoting ICC does not rely on any special approach or method, but on "the integrity as a person and the relationships that [he/she is] able to develop in the classroom". Therefore, it is not the new method or approach, but rather the ability to "build and maintain human relationships" (p. 32) that guarantees the success in developing ICC among EFL learners.

\subsection{Intercultural competence in foreign language primary classroom}

According to Sercu (2005, pp. 10-11), ICC development does not seem to be very popular among EFL teachers. Having investigated the issue in seven countries, including Poland, he concluded that, with respect to integration of ICC into foreign language education, teachers can be divided into two basic groups: those in favour of the ICC development in FL education and those, including Polish teachers, believing language and culture integration in a FL classroom is not possible. Still, even the so-called "favourably disposed foreign language teachers" do not reflect their beliefs about ICC in the classroom. In general, it seems that they do not pay more attention to extensive culture teaching than "the unfavourably disposed foreign language teachers".

Considering ELT materials, Siek-Piskozub (2014) outlines that many of them do not focus on building ICC, but rather treat culture as a supplementary element. As a result of this, many teachers do not feel the necessity to develop intercultural competence among their learners and tend to focus solely on communicative competence. The scarce emphasis on the development of ICC is merely present in materials for advanced and mature students. Having investigated the issue of secondary school EFL learners' response to culture-related texts, Chodkiewicz and Kwiatek (2015, pp. 34-35) found out that for the majority of the students such texts are not interesting or thought-provoking, and do not generate high cognitive engagement in text processing. When it comes to primary school learners, SiekPiskozub (2014) notices that the problem receives no attention, leaving behind the needs of young FL learners. 
Still, it is the role of early educators to engage with ongoing learning and reflective practice in order to make the learners culturally competent. In other words, it is necessary to build intercultural competence from the very beginning of primary education, especially in the age of globalisation. In the words of Sercu (2005),

all foreign language educators [including primary school teachers] are now expected to exploit [the potential of foreign language education being intercultural $][\ldots]$ and promote the acquisition of intercultural competence in their learners (pp. 1-2).

Indeed, cultural awareness is advocated by such authors as Coyle, Hood and Marsh (2010) who see the importance of language, culture and cognitive processing when establishing connections in Content and Language Integrated Learning. As they point out, culture determines the way people perceive the world, and language is to express that. Therefore, CLIL provides learners with intercultural experience they would not have a chance to practise in a monolingual classroom. Without "intercultural experiences, [a thorough understanding of] global citizenship" (p. 39) is not possible. Hence, the idea behind building cross-curricular links between foreign language and other subjects seems to facilitate learning in the primary classroom.

\section{The study}

Responding to the need of the development of ICC in the primary classroom, a small-scale study with the primary second graders was conducted in the context of online education. The study involved a series of EFL lessons whose content was related to the topics in the Polish primary curriculum, and integrated with the cultural material currently taught in the online classroom by the early school education teacher. It needs to be mentioned that in Poland, EFL teaching programme is not a part of the integrated primary curriculum. English as a foreign language is taught as a separate subject from the $1^{\text {st }}$ grade onwards. Therefore, the present study constitutes an avenue for a connection of language and the curriculum content.

\subsection{Purpose of the study}

The study had two objectives. First, it served to provide the researchers with some reflections on the issue of possible integration of EFL lessons with the content of the lower primary curriculum in the Polish school. Second, it was aimed to find out how young learners perceived such lessons and how useful the activities were for developing intercultural awareness among the pupils. We examined the learners' questionnaires concerning their perception of the lessons as well as their knowledge related to certain aspects of intercultural competence. 


\subsection{Method}

During a period of a month and a half, six lessons were conducted in each of the two groups of primary school second graders who received online education during the lockdown period of the COVID-19 pandemic. The lessons were 45 minutes long and covered the following topics: Teeth and Tooth Fairy, Easter, Entertainment, Drama, Theme Park, Environment. All of them were strictly integrated with other Polish lessons the students attended during a particular week. The cultural aspects were taught in the background of language practice. Contrary to the learners' traditional EFL lessons, our classes were organised in accordance with the principles of ICC presented below:

Table 1. Principles of ICC and their implementation in the lessons (based on Byram, 1994, p. 15)

\begin{tabular}{|c|c|c|}
\hline Goals of ICC & Meeting the ICC goals in the study \\
\hline 2. & $\begin{array}{c}\text { Appreciate the similarities and } \\
\text { differences between ss' own culture } \\
\text { and cultures of the countries where } \\
\text { the target language is spoken }\end{array}$ & $\begin{array}{c}\text { Cross-curricular links between English and Polish } \\
\text { lessons instead of culture as a separate unit in EFL } \\
\text { coursebooks }\end{array}$ \\
\hline $\begin{array}{c}\text { Identify with the experience } \\
\text { and perspective of people in the } \\
\text { countries and communities where } \\
\text { the target language is spoken }\end{array}$ & $\begin{array}{c}\text { Language tasks enabling experiencing culture from } \\
\text { the native speaker perspective (cultural shock) } \\
\text { instead of language activities and cultural facts } \\
\text { separately }\end{array}$ \\
\hline 3. & $\begin{array}{c}\text { Use this knowledge to develop } \\
\text { a more objective view of ss' own } \\
\text { customs and ways of thinking }\end{array}$ & $\begin{array}{c}\text { The elements of foreign culture in the background } \\
\text { of EFL lessons related to corresponding elements } \\
\text { of ss' native culture included in the Polish primary } \\
\text { programme }\end{array}$ \\
\hline
\end{tabular}

\subsubsection{Participants}

The learners comprised two groups between 7 and 8 years of age ${ }^{1}$. There were 20 and 22 members in each group, all in the second grade of the primary school in Poland. Their level of English was A1 according to CEFR. They had two EFL 45-minute lessons per week. The content of the lessons was taught online with a special emphasis placed on teaching vocabulary. Cultural aspects were taught as separate lessons at the end of each unit and were not directly related to the content of the unit. Their knowledge of culture was rather factual and limited to some songs, rhymes or specific vocabulary they had to learn by heart and use while completing exercises in the activity book.

1 Due to the young age of the students, the researchers obtained written consents for research participation from their parents. 


\subsubsection{Materials}

The first research tool for our study were lesson plans built on the subject-integrated education main coursebook for second graders of the state primary school (Lorek \& Zatorska, 2015). The topics of the lessons were selected in such a way as to follow the material currently taught during the lessons in Polish with regard to certain elements of culture. In order to design the classroom tasks, a reference to various EFL materials corresponding to the themes chosen was necessary. The designed materials for our lessons were mainly based on the resources provided by British Council: Teaching Kids available online and Tiger 2 coursebook for state school second graders.

The second instrument used in the current study was the same questionnaire given to the students after each lesson with a view to collecting information concerning their perception of the designed lessons and investigating some aspects of their cultural awareness. Due to the participants' age and limited English proficiency, the questionnaire was conducted in their native language. In the questionnaire, the students were asked both closed and open questions. The former concerned their perception of the lesson while the latter were to investigate whether their level of ICC related to a particular issue raised after the lesson. The open questions were related to practical experience (practising real life situations), linguistic elements (vocabulary and grammar), and passive experience (facts about culture).

\subsubsection{Design and procedure}

The lesson plans were based on classroom strategies designed by Coyle and Verdu (2000) in accordance with the five instructional phases:

Motivation aimed at building new knowledge on the previous one. The teacher introduced students into the topic by organising the learning environment and activating learners' knowledge with regard to certain aspects of their native culture ${ }^{2}$ that had been practised during their classes in Polish;

Input aimed at developing learners' comprehension and retention of the new material. The teacher presented and modelled new foreign language content by means of visuals, video sequences, gestures, etc.;

Controlled Practice aimed at practising new material. At this stage the students were engaged in identifying gestures showed by the teacher, answering teacher's questions, and matching pictures with the words, or completing missing letters in

2 Obviously, in the age of globalisation, native culture cannot be called homogenous and isolated. In many cases, some aspects can be much similar. Hence, in line with Siek-Piskozub (2014), it is not our aim to search for differences, neither similarities, but rather to build the elements of foreign culture on the native one. 
the words. The role of the teacher also included guidance and necessary correction of their language use;

Semi-Controlled Practice aimed at promoting social and cooperative interaction by means of whole-class work where the teacher only monitored and helped students when it was necessary3;

Transfer Phase aimed at promoting students' independence so that they could use language autonomously and the teacher's support was greatly diminished.

Each lesson designed for the purpose of the current study followed the abovementioned phases. Clearly, the selected topics, materials and activities differed, yet, it was of paramount importance for us to keep the same scheme of all the lessons in order to maintain the same criteria in the questionnaires completed by the participants.

\subsection{Results and discussion}

Question number one of the questionnaire the students filled in during each lesson concerned students' evaluation of the lesson. The aim was to get students' general impression about the lesson. The students were to choose from three answers: yes, a little, no that were identified as positive, neutral, and negative response, respectively. Depending on the topic of the lesson, the answers to choose from varied, but each time they corresponded to the three categories: hands-on experience of cultural aspects, linguistic elements, and passive experience of cultural aspects. By hands-on experience, we understand any cultural aspect experienced by the learners in a practical way, e.g. searching for the eggs hidden in the online classroom, by linguistic element, we understand elements of language, such as grammar or vocabulary, by passive experience we mean experience such as watching a video or listening to a song.

1. Did you like the lesson?

Table 2. The students' general evaluation of the lessons

\begin{tabular}{|c|c|c|c|}
\hline lesson & positive & neutral & negative \\
\hline 1 & $85 \%$ & $12.5 \%$ & $2.5 \%$ \\
\hline 2 & $78 \%$ & $22 \%$ & 0 \\
\hline 3 & $77.5 \%$ & $20 \%$ & $2.5 \%$ \\
\hline 4 & $77.5 \%$ & $20 \%$ & $2.5 \%$ \\
\hline 5 & $74 \%$ & $21 \%$ & $5 \%$ \\
\hline 6 & $78 \%$ & $22 \%$ & 0 \\
\hline
\end{tabular}

3 Coyle and Verdu (2000) suggest doing pair-work or group-work in this phase, however, taking into consideration the age of the learners and the context of online teaching, it has been changed into whole-class work in the present study. 
As shown in Table 2, the results clearly indicate that the vast majority of the learners evaluated the lessons in a positive way, and only a small percentage declared some negative impression as regards the four lessons. This means that most learners perceived the culture-based online lessons as attractive and engaging for them.

In order to evaluate the scope of cultural aspects acquired by the participants, it is not only the general impression that matters, but also the comprehension of the lesson. For this reason, the aim of the second question was to get some insight into the perceived understanding of the content and language.

2. Was the lesson easy?

Table 3. The students' perceptions of the difficulty of each lesson

\begin{tabular}{|c|c|c|c|}
\hline lesson & positive & neutral & negative \\
\hline 1 & $85 \%$ & $10 \%$ & $5 \%$ \\
\hline 2 & $65 \%$ & $35 \%$ & 0 \\
\hline 3 & $65 \%$ & $33 \%$ & $2 \%$ \\
\hline 4 & $70 \%$ & $30 \%$ & 0 \\
\hline 5 & $71 \%$ & $29 \%$ & 0 \\
\hline 6 & $54 \%$ & $38 \%$ & $8 \%$ \\
\hline
\end{tabular}

It is noticeable from Table 3 that the majority of the learners found each lesson relatively easy. Hence, it might be concluded that the material chosen for our lessons seemed to be in accordance with their level. As expected, lesson 6 appeared to be the most difficult, which might have been caused by the subject connected with environmental issues where the vocabulary was slightly above the level of second graders. The fact that the lessons were conducted in an online setting does not seem to have hampered the students' understanding of the contents covered.

3. What was the most interesting?

Table 4. Interesting elements of the lessons as perceived by the students

\begin{tabular}{|c|c|c|c|}
\hline lesson & $\begin{array}{c}\text { element of culture } \\
\text { (practical experience) }\end{array}$ & $\begin{array}{c}\text { linguistic } \\
\text { element }\end{array}$ & $\begin{array}{c}\text { element of culture } \\
\text { (passive experience) }\end{array}$ \\
\hline 1 & $32 \%$ & $12 \%$ & $56 \%$ \\
\hline 2 & $92 \%$ & $3 \%$ & $5 \%$ \\
\hline 3 & $60 \%$ & $32.5 \%$ & $7.5 \%$ \\
\hline 4 & $70 \%$ & $27 \%$ & $3 \%$ \\
\hline 5 & $50 \%$ & $18 \%$ & $32 \%$ \\
\hline 6 & $54 \%$ & $22 \%$ & $24 \%$ \\
\hline
\end{tabular}


Evidently, the learners found elements of culture in the form of practical experience the most interesting. While it appears that the linguistic side of the lesson was also important for them, the least enjoyable were the elements of culture presented in the form of pure facts. These seem to be in accordance with the researchers' post-lesson reflections that showed not only the importance of practical experience, but also language comprehension.

4. What was the most difficult?

Table 5. The students' perceptions of the difficulty of the selected elements of the lessons

\begin{tabular}{|c|c|c|c|}
\hline lesson & $\begin{array}{c}\text { element of culture } \\
\text { (practical experience) }\end{array}$ & $\begin{array}{c}\text { linguistic } \\
\text { element }\end{array}$ & $\begin{array}{c}\text { element of culture } \\
\text { (passive experience) }\end{array}$ \\
\hline 1 & 0 & $93 \%$ & $7 \%$ \\
\hline 2 & $5.5 \%$ & $89 \%$ & $5.5 \%$ \\
\hline 3 & $27 \%$ & $54 \%$ & $19 \%$ \\
\hline 4 & $30 \%$ & $51 \%$ & $19 \%$ \\
\hline 5 & $29 \%$ & $33 \%$ & $38 \%$ \\
\hline 6 & $56 \%$ & $35 \%$ & $9 \%$ \\
\hline
\end{tabular}

Although the learners paid attention to the linguistic elements during the lesson and found them relatively interesting, it turns out that this was the most difficult part of the lesson. They may have not enjoyed the facts about cultural issues much due to the fact that these matters were not challenging for them. The elements of culture in the form of practical experience were the most interesting for the participants of our study, but apparently they were not the most difficult for them.

5. What new did you learn?

Table 6. The students' self-assessment of new language- and culture-related knowledge and skills

\begin{tabular}{|c|c|c|c|}
\hline lesson & $\begin{array}{c}\text { element of culture } \\
\text { (practical experience) }\end{array}$ & $\begin{array}{c}\text { linguistic } \\
\text { element }\end{array}$ & $\begin{array}{c}\text { element of culture } \\
\text { (passive experience) }\end{array}$ \\
\hline 1 & $6 \%$ & $76 \%$ & $18 \%$ \\
\hline 2 & $27 \%$ & $54 \%$ & $19 \%$ \\
\hline 3 & $54 \%$ & $20 \%$ & $26 \%$ \\
\hline 4 & $57 \%$ & $20 \%$ & $23 \%$ \\
\hline 5 & $37 \%$ & $29 \%$ & $34 \%$ \\
\hline 6 & $42 \%$ & $36 \%$ & $22 \%$ \\
\hline
\end{tabular}

Considering the learners' feelings about new issues that they learned during the classes, we might say that the elements of culture presented as pure facts were 
not novel for the participants. What they considered new was the vocabulary and aspects of culture in the form of practical experience. Hence, it might be concluded that it is not the factual information, but rather practical experience related to selected aspects of culture together with the linguistic elements that seem to be the most effective and needed when teaching English as a foreign language and developing ICC among young learners.

6. Enumerate 3 things you remember best:

Table 7. The students' self-assessment of best remembered elements of the lessons

\begin{tabular}{|c|c|c|c|}
\hline lesson & $\begin{array}{c}\text { element of culture } \\
\text { (hands-on experience) }\end{array}$ & $\begin{array}{c}\text { linguistic } \\
\text { element }\end{array}$ & $\begin{array}{c}\text { element of culture } \\
\text { (passive experience) }\end{array}$ \\
\hline 1 & $9 \%$ & $18 \%$ & $73 \%$ \\
\hline 2 & $51 \%$ & $22 \%$ & $27 \%$ \\
\hline 3 & $49 \%$ & $20 \%$ & $31 \%$ \\
\hline 4 & $57 \%$ & $23 \%$ & $20 \%$ \\
\hline 5 & $37 \%$ & $34 \%$ & $29 \%$ \\
\hline 6 & $36 \%$ & $22 \%$ & $42 \%$ \\
\hline
\end{tabular}

Although in Lesson 1 and 6 the learners' remembered the elements of passive experience best, the results from the four remaining classes show that it is culture in the form of practical experience that seems to be stored in young learners' memory better. Taking into account the overall response to introducing elements of culture as practical experience, it might be stated that such a form of learning seems to be more efficient than presenting the learners with pure facts relating to some aspects of culture.

\section{Conclusions}

The study showed that culture is neither to be viewed as the additional fifth element attached to the four skills, nor as the knowledge of facts about foreign countries and their people. It should be perceived as the background integrated into the linguistic content dealt with at each educational level (Byram \& Morgan, 1994; Corbet, 2003; Kramsch, 1993). Nonetheless, it seems that the issue has not received sufficient attention with regard to the primary classroom (Sercu, 2005; Siek-Piskozub, 2014).

In general, it might be concluded that culture integrated lessons as such as well as their content were evaluated in a positive way by young learners. It seems that not only practical experience of cultural aspects but also language practice should be highlighted when developing some aspects of intercultural competence among primary school students. As expected at the beginning, culture presented 
in the form of pure facts apparently does not guarantee effective learning. The use of native culture elements blended thematically with subject-integrated education provides better comprehension of culture-based EFL lessons by young learners. Therefore, the idea of integrating culture and foreign language teaching with cross-curricular education in state schools appears to be an effective tool when attempting to promote basic elements of intercultural competence among young learners also in the context of online education. Yet, taking into account the limitations of the current study, namely a relatively small sample as well as the length of the treatment phase, the authors believe the issues addressed in this article will be an interesting avenue for further longitudinal research.

\section{References}

Brewster, J. (2002). The Primary English Teacher's Guide. Harlow: Penguin English.

Byram, M. (1997). Teaching and Assessing Intercultural Communicative Competence. Clevedon: Multilingual Matters.

Byram, M., \& Morgan, C. (1994). Teaching and Learning Language and Culture. Great Britain: WBC.

Chodkiewicz, H., \& Kwiatek, M. (2016). Secondary school EFL learners' response to coursebook culture-focused texts. Kwartalnik Neofilologiczny, 63(1), 20-37.

Corbett, J. (2003). An Intercultural Approach to English Language Teaching. Clevendon: Multilingual Matters Ltd.

Coyle, D., Hood, P., \& Marsh, D. (2010). Content and Language Integrated Learning. Cambridge: Cambridge University Press.

Coyle, Y., \& Verdu, M. (2000). Teaching strategies in the EYL classroom. In J. Moon, \& M. Nikolov (Eds.), Research into Teaching English to Young Learners: International Perspectives (pp. 257-294). Pecs: University Press Pecs.

Fillmore, C. (1982). Frame Semantics. In D. Geeraerts (Ed.), Cognitive Linguistics: Basic Readings (pp. 111-137). Berlin: De Gruyter.

Gill, S., \& Cankova, M. (2002). Intercultural Activities. Oxford: Oxford University Press.

Kramsch, C. (1993). Context and Culture in Language Teaching. Oxford: Oxford University Press.

Kramsch, C. (2001). Language and Culture. Oxford: Oxford University Press.

Lorek, M., \& Zatorska, M. (2015). Nasza Szkoła: Podręcznik do Szkoły Podstawowej, Klasa 2, Czesść 3. Warszawa: MEN.

Malinowski, B. (1923). The problem of meaning in primitive languages. In C. K. Ogden, \& I. A. Richards (Eds.), The Meaning of Meaning. A Study of the Influence of Language upon Thought and of Science upon Symbolism (pp. 296-366). New York: Harcourt, Brace \& World, Inc.

Sercu, L. (2005). Teaching foreign languages in an intercultural world. In L. Sercu, E. Bandura, P. Castro, L. Davcheva, C. Laskaridou, U. Lundgren ... \& P. Ryan (Eds.), Foreign Language Teachers and Intercultural Communication. An International Investigation (pp. 1-18). Clevedon: Multilingual Matters. DOI: 10.21832/9781853598456-003.

Siek-Piskozub T. (2014). From communicative competence to intercultural communicative competence: A new proposal for language skills. In H. Chodkiewicz, \& M. Trepczyńska (Eds.), Language skills: Traditions, Transitions and Ways Forward (pp. 18-33). Newcastle upon Tyne, UK: Cambridge Scholars Publishing.

Tomalin, B., \& Stempleski, S. (1993). Cultural Awareness. Oxford: Oxford University Press.

Wierzbicka, A. (1997). Understanding Cultures through their Key Words. Oxford: Oxford University Press. 